\title{
Nilai-Nilai Tasawut Dalam Kitab Simthu Ad-Durar Karya Habib Ali Bin Muhammad Al-Habsyi
}

\author{
Achmad Syukron Abidin \\ Mahasiswa S2 UIN Sunan Kalijaga \\ E-Mail: aibidinsyukron76@gmail.com
}

\begin{abstract}
Abstrak
Kitab Simthu ad-Durar sebagai kitab yang menceritakan kehidupan nabi juga tidak lepas dari nilai-nilai akhlak dan doktrin tasawuf. Karena dalam Simthu ad-Durar sendiri menceritakan tentang orang yang menjadi sauri teladan dalam setiap tindak tanduk beliau. Unsur akhlak sebagai salah satu cabang tasawuf bisa di lihat pada ungkapan Habib Ali dalam menjelaskan tentang nabi Muhammad sebagai suri teladan yang baik. Dalam Simtut Durar pun nilai-nilai akhlak dan tasawuf sangat kental. Habib Ali membungkus nilai-nilai itu dengan gaya bahasa yang indah dan mudah dipahami dan diresapi bagi pembacanya.
\end{abstract}

Kata Kunci: Tasawuf, Nilai, Akhlak, Ali al-Habsyi, Simthu ad-Durar 
Achmad Syukron Abidin

Nilai-Nilai Tasawuf Dalam Kitab Simthu Ad-Durar

Karya Habib Ali bin Muhammad Al-Habsyi

\begin{abstract}
The book of Simthu ad-Durar as a book that tells the life of the prophet is also inseparable from moral values and the doctrine of Sufism. Because in Simthu adDurar itself tells of a person who is a role model in his every action. Moral elements as a branch of Sufism can be seen in Habib Ali's expression in explaining the prophet Muhammad as a good role model. In Simthu ad-Durar the values of morals and Sufism are very thick. Habib Ali wraps these values in a beautiful language style that is easy to understand and permeates the reader.
\end{abstract}

Keywords: Sufism, Value, Morals, Ali al-Habsyi, Simthu ad-Durar

\title{
A. Pendahuluan
}

Bahasa merupakan salah satu media komunikasi dalam segala aspek, termasuk dalam sebuah karya sastra. Bahasa terbagi menjadi dua yaitu ragam bahasa lisan dan tulisan. Dalam penelitian ini peneliti menggunakan ragam bahasa tulisan yang menjadi objek kajiannya. Ragam bahasa tulis adalah pengungkapan dan pengaplikasiannya tidak menggunakan anggota-anggota badan sebagai alat penggeraknya sebab sebab ragam ini berupa tulisan. Ragam bahasa tulis berhubungan dengan keseluruhan bahasa dari hasil pilihan kata yang disusun menjadi sebuah kalimat, alinea hingga paragraf, teks dan wacana. Teks yang ditulis berupa karya ilmiah seperti buku, artikel, jurnal dan sebaginya, juga berupa karya sastra puisi, buku, naskah, novel termasuk juga berupa karya sastra berupa kitab.

Sebuah teks tidaklah lahir dari kekosongan, pengarang ingin menyampaikan makna dan pesan lewat teks yang dibuatnya tidak bisa lepas dari konteks dan pikiran sebelumnya yang mempengaruhi pengarang. Oleh karena itu, teks tidak dapat lepas dari hal-hal yang menjadi latar belakang penciptaannya, baik secara umum maupun khusus. Suatu teks itu penuh dengan makna bukan hanya karena memiliki struktur tertentu, suatu kerangka yang menentukan dan 
Achmad Syukron Abidin

Nilai-Nilai Tasawuf Dalam Kitab Simthu Ad-Durar Karya Habib Ali bin Muhammad Al-Habsyi

mendukung bentuk, juga karena teks ini berhubungan dengan teks lain.

Kitab Simthu ad-Durar merupakan salah satu karya sastra yang terkenal di kalangan umat Islam. Simthu ad-Durar ini merupakan sebuah buku teks yang bernafaskan Islam yang tujuannya untuk dakwah melalui seni. Juga merupakan kitab sastra yang menceritakan tentang biografi atau sejarah hidup Nabi Muhammad saw. sejak awal sebelum lahir sampai wafatnya.

Kitab Simthu ad-Durar yang berjudul lengkap Simthu ad-Durar fi Akhbar Maulid Khairil al-Basyar wa Ma Lahu min Akhlak wa Aushaf wa Syiar (Untaian Mutiara Kisah Kelahiran Manusia Utama; Akhlak, Sifat dan Riwayat hidupnya) yang dikarang oleh Habib Ali bin Muhammad al-Habsyi disajikan dalam bentuk prosa, syair puitis serta menggunakan bahasa yang indah yang tidak kalah menarik dengan karya kisah atau biografi nabi Muhammad saw. lain seperti kitab maulid al-Barzanji karya sayyid Ja'far bin Husain bin Abdul Karim AlBarzanji dan kitab maulid al-Diba'i karya syaikh Abdurrahman bin Ali bin Muhammad bin Umar bin Ali bin Yusuf bin Ahmad bin Umar AlDiba”i Asy Syaibani.

Nilai-nilai yang terdapat dalam kitab Simthu ad-Durar juga tidak bisa lepas dari pengaruh ajaran Islam, termasuk pengaruh akhlak dan tasawuf. Karena dalam Simthu ad-Durar sendiri menceritakan tentang orang yang menjadi sauri teladan dalam setiap tindak tanduk beliau. Unsur ahlak sebagai salah satu cabang tasawuf bisa dilihat pada ungkapan Habib Ali dalam menjelaskan tentang nabi Muhammad sebagai suri teladan yang baik.

Kitab Simthu ad-Durar sebagai kitab yang menceritakan kehidupan nabi juga tidak lepas dari doktrin tasawuf salah satunya adalah tentang Nur Muhammad. Untuk mendapatkan nilai-nilai tasawuf dalam Simthu ad-Durar penulis menggunakan metode analisis isi. Dengan metode analisis isi diharapkan dapat mendiskripsikan isi dari Simthu ad-Durār. Untuk mendapatkan kandungan isi Simthu 
Achmad Syukron Abidin

Nilai-Nilai Tasawuf Dalam Kitab Simthu Ad-Durar

Karya Habib Ali bin Muhammad Al-Habsyi

ad-Durar terutama dalam masalah tasawuf dan akhlak, dan untuk menemukan pesan yang spesifik dalam Simthu ad-Duraryang disajikan dengan bentuk prosa, syair puitis, diperlukan teori yang tepat untuk menganalisisnya.

\section{B. Biografi Habib Ali bin Muhammad al-Habsyi}

Habib Ali bin Muhammad al-Habsyi lahir pada hari Jum,at 24 Syawal 1259 H, di Qasam ${ }^{1}$ sebuah kota di Hadramaut, Yaman. Ia dibesarkan langsung di bawah asuhan kedua orang tuanya. ${ }^{2}$ Ayahnya adalah al-Arif billah Muhammad bin Husain bin Abdullah al-Habsyi, seorang mufti Syafi'iyah di Haramain yang terkenal dengan ulama yang senantiasa mencurahkan jiwa dan raga untuk berdakwah menyiarkan perintah dan larangan Allah SWT. dari desa ke desa, dari kota ke kota, bahkan dari negara satu ke negara yang lain. Tujuannya adalah menyebarkan ilmu, mengusir kebodohan, dan meneruskan panji yang sebelumnya di bawa leluhurnya, Nabi Muhammad swt. ${ }^{3}$

Adapun silsilah Habib Alial-Habsyi yang sampai nabi Muhammad adalah sebagai berikut: Ali bin Muhammad bin Husai bin Abdullah bin Syeikh bin Abdullah bin Muhammad bin Husain bin Ahmad Shahibusy Si'ib bin Muhammad Ashgar bin Alwi bin Abu Bakar al-Habsyi bin Ali bin Ahmad bin Muhammad Asadullah bin Hasan at-Turabiy bin Ali bin Sayyidina al-Imam al-Faqih al-Muqaddam Muhammad bin Sayyidina Ali bin Sayidina al-Imam Muhammad bin Sayyidina al-Imam Khali' Qasam bin Sayyidina Alwi bin Sayyidina al-Imam Muhammad bin Sayyidina al-Imam Ubaidillah bin Sayyidina al-Imam Muhajir Ahmad bin Sayyidina al-Imam Isa ar-Rumi bin Sayyidina al-Imam Muhammad an-Naqib bin Sayyidina al-Imam Ali al-Uryadhi bin Sayyidina Jafar asSodiq bin Sayyidina al-Imam Muhammad al-Baqir bin Sayyidina Imam

1 Qasam adalah suatu kota yang namanya dinisbatkan kepada Ali bin Alwi Khali Qasam $(529$ H), lihat Husain Anis al-Habsyi, Biografi Habib Ali al-Habsyi Muallif Maulid Simthu a-Durar, (Solo: Pustaka Zawiyah, 20G) h.15

2 Thaha bin Husain al-Thaqaf, Fuyudad al-Bahr al-Mail, (Madinah: Jami al-Huquq Mahfudah, 2005), 13-14

3 Ibid., 22 
Achmad Syukron Abidin

Nilai-Nilai Tasawuf Dalam Kitab Simthu Ad-Durar Karya Habib Ali bin Muhammad Al-Habsyi

Ali Zainal Abidin bin Husain bin Fatima az-Zahra binti Rasulullah saw. ${ }^{4}$

Sejak kecil Habib Ali dididik langsung oleh kedua orang tuanya. Namun pada usianya yang ke-7 ayahnya Habib Muhammad berangkat ke Makkah dan tinggal di sana. Sehingga kepengasuhan Habib Ali langsung dipegang oleh ibundanya Habibah Alawiyyah dan para guru yang ada di sekitar tempat kelahirannya. Dalam usia yang sanngat muda Habib Ali sudah mampu menguasai berbagai ilmu baik ilmu lahir maupun batin. Hal itu dikarenakan dengan kegemarannya begadang (sahrul layali) mutala'ah kitab. ${ }^{5}$

Habib Ali diminta untuk segera menikah oleh ibunya. Beliau diminta menikah dengan wanita yang berasal dari Qasam. Dari pernikahan dengan wanita Qasam, beliau dikaruniai anak bernama Abdullah. ${ }^{6}$

Setelah menikah, Habib Ali disuruh ibunya untuk menunaikan Haji dengan cara menghajikan orang yang biayanya ditanggung oleh orang yang dihajikan itu. Pada saat di Makkah Habib Ali berkunjung ke rumah ayahnya. Dan setelah urusan Haji selesai, beliau meminta izin untuk kembali ke Hadramaut.

Pada tahun berikutnya Habib Ali menunaikan ibadah Haji lagi. Inipun dikerjakan atas perintah ibundanya. Berbeda dengan ibadah Haji yang pertama, untuk ibadah haji kali ini biayanya ditanggung oleh Hasan bin Ahamd al-Aidrus. Di tengah perjalanan Habib Ali beserta rombongan singgah di Syihr. Pada kesempatan inilah Habib Ali bertemu dengan Habib Abu Bakar al-Athas. Yang pada nantinya menjadi guru ruhaninya. Pada pertemuan pertama Habib Ali kagum dengan Habib Abu Bakar. Hingga ia tidak mau berpisah dengannya.

Keesokan harinya Habib Ali Bersama masyarakat berjamaah dengan Habib Abu Bakar di Masjid Amr. Selama tiga belas hari Habib

\footnotetext{
4 Thaha bin Husain al-Thaqaf, Fuyudad al-Bahr al-Mail, 13-14

5 Ibid., 39

6 Husain Anis al-Habsyi, Biografi Habib Ali al-Habsyi Muallif Maulid Simtud Durar, h. 29
} 
Achmad Syukron Abidin

Nilai-Nilai Tasawuf Dalam Kitab Simthu Ad-Durar

Karya Habib Ali bin Muhammad Al-Habsyi

Ali tinggal Bersama Habib Abu Bakar. Habib Ali membacakan kitab ar-Rasyafat dihadapan Habib Abu Bakar. Dan habib Abu Bakar menerangkan dan melimpahkan ilmunya kepada Habib Ali dan kepada hadirin yang hadir. ${ }^{8}$

Setelah mengkhatamkan kitab ar-Rasyafat, Habib Ali beserta rombongan mengikuti Habib Abu Bakar pergi ke Mukalla. Di tempat ini para rombongan menginginkan ijazah dari Habib Abu Bakar, Habib Abu Bakar pun memberikan mereka ijazah dan berwasiat untuk berziarah ke makam Rasulullah saw. Dan setelah itu mereka berpisah.

Sepulang dari menunaikan ibadah Haji pada tahun 1278 H Habib Ali bertemu dengan gurunya lagi Habib Abu Bakar. Habib Abu Bakar saat itu berkunjung ke Seiwun dalam rangka bertemu dengan Muhammad bin Ali as-Seggaf. Di sini Habib Abu Bakar menguji kesabaran Habib Ali dengan tidak membukakan pintu untuknya, namun Habib Ali dengan sabar menunggu. Dan setelah sekian lama menunggu akhirnya Habib Abu Bakar menyuruh Muhammad as-Seggaf untuk menyampaikan pesan kepada Habib Ali supaya menemui Habib Abu Bakar dirumah Abdul Qadir bin Hasan as-Seggaf. ${ }^{9}$ Habib Ali mengangap Habib Abu Bakar sebagai pembimbing ruhaninya, sedangkan ayahnya Habib Muhammad sebagai pembimbing jasmani. ${ }^{10}$

Nama Habib Ali begitu terkenal sehingga beliau diangkat menjadi Imam di Masjid Hambal. Beliau menjadi imam di sana selama tiga puluh tahun. Lamanya, selama itu beliau mengajarkan ilmu lahir dan tidak menyibukkan diri dengan ilmu batin. Hal ini sesuai dengan pesan gurunya Habib Abu Bakar. Masjid itu pun begitu ramai dengan orang yang beribadah dan menuntut ilmu, hingga Habib Ali mempunyai arRibath (pondok pesantren). ${ }^{11}$

7 Kitab syair sufistik karya Habib Abdurrahman bin Abdullah Bafaqih

8 Husain Anis, Biografi Habib Ali al-Habsyi Muallif Maulid Simtud Durar, 31

9 Ibid., 49

10 Ibid., 39

11 Ibid., 50 
Achmad Syukron Abidin Nilai-Nilai Tasawuf Dalam Kitab Simthu Ad-Durar Karya Habib Ali bin Muhammad Al-Habsyi

Dalam mengembangkan dan mengamalkan ilmunya Habib Ali membangun ar-Ribath (pondok pesantren) di Seiwun. Ar-Ribath ini merupakan ribat yang dibangun pertama kali di Hadramaut. Ribat ini dibangun dan di khususkan bagi penuntut ilmu yang datang dari dalam ataupun luar kota. Habib Ali membangun kamar dan fasilitas lainya guna tempat tinggal mereka. Bahkan makan pun Habib Ali menanggungnya sendiri.

ar-Ribath ini begitu sering dikunjungi orang-orang yang menuntut ilmu. Ketika seseorang telah menyelesaikan pelajarannya, maka aka nada orang yang lain yang menggantikannya. Ribat ini sangat ramai sehingga Habib Ali mendengar gemuruh orang-orang yang membaca al-Qur'an, berzikir dan belajar. ${ }^{12}$

Habib Ali tidak berbeda dengan halnya manusia biasa. Beliaujuga bisa merasa sakit. Seiring dengan usianya yang semakin bertambah penglihatan beliau semakin kabur. Hingga dua tahun sebelum wafatnya beliau, penglihatan beliau hilang sama sekali. Keadaan kesehatan beliau pun semakin buruk. Akhirnya pada waktu Zuhur hari Minggu 20 Rabi'u as-Sani $1333 \mathrm{H}$ beliau dipanggil oleh Allah. Pada waktu Ashar keesokan harinya, jenazah beliau dishalatkan di halaman masjid Riyad yang diimami oleh anak dan khalifah beliau setelah itu jenazah beliau diantarkan ke kubur dengan iring-iringan tiada awal dan ahirnya. Beliau dimakamkan di sebelah barat masjid Riyad. ${ }^{13}$ Dalam wasiatnya Habib Ali menunjuk putra beliau Habib Muhammad bin Ali al-Habsyi sebagai penggantinya. ${ }^{14}$

Habib Alwi bin Ali putra dari Habib Ali al-Habsyi setiap tahunnya menyelenggarakan Haul di kota Surakarta. Habib Alwi-lah yang pertama kali menggelar Haul sang ayah. Masyarakat dari berbagai daerah datang menghadiri Haul. Dalam Haul tersebut disampaikan ceramah, nasihat, dan pidato ilmiah. Beliau tinggal dan melanjutkan kegiatan-kegiatan yang telah dilakukan oleh ayahnya di Surakarta.

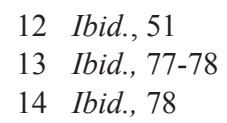


Achmad Syukron Abidin

Nilai-Nilai Tasawuf Dalam Kitab Simthu Ad-Durar

Karya Habib Ali bin Muhammad Al-Habsyi

Selain berdakwah keliling kota, sehingga muridnya menjangkau ribuan orang dan merata di berbagai tempat. Disana di bangun masjid Ar-Riyadh beserta Ribath atau zawiyah semacam pesantren dan tempat pengajian ala Hadramaut sebagai pusat kegiatan dakwahnya. Di masjid Riyadh itulah Habib Alwi menyelenggarakan kegiatan ibadah dan taklim. ${ }^{15}$ Masjid tersebut dibangun pada tahun 1953. Setelah Habib Alwi wafat, kepemimpinan masjid Riyad di Solo berbindah kepada Habib Anis bin Alwi al-Habsyi. Dan sekarang sudah digantikan oleh Habib Husain bin Anis bin Alwi bin Ali al-Habsyi. Dan tradisi Haul Habib Ali masih ada sampai sekarang.

\section{Simthu ad-Durar: Sejarah Penulisan}

Simthu ad-Durar adalah salah satu karya tentang sejarah nabi Mauhammad yang dikarang oleh salah satu ulama kenamaan pada masanya yaitu Habib Ali bin Muhammad al-Habsyi. Karyanya tidak kalah popular dengan karya-karya sebelumnya yang sudah menjadi santapan rohani para pencinta nabi Muhammad. Diantara karya yang popular sebelum munculnya Simthu ad-Durar adalah Barzanji karya Syekh Jafar al-Barzanji dan adz-Dziba' karya Syekh Abdurrahman $a d z-$ Dziba'.

Setiap tahun Habib Ali bin Muhammad al-Habsyi meyelenggarakan peringatan lahirnya Nabi Muhammad. Dengan membaca maulid adz-Dziba' sebelum beliau mengarang Simthu ad-Durar. Kegiatan itu diselenggarakan setiap hari Kamis pada akhir bulan Rabiul Awwal dengan dihadiri para ulama dan para pemimpin di daerah tersebut. ${ }^{16}$

Salah satu riwayat mengatakan bahwa pada hari kamis 26 Safar 1327H, Habib Ali memulai khotbah mukadimah Simthu ad-Durar yang bunyinya adalah sebagai berikut:

$$
\text { الحمدلله القوي سلطانه * الو اضح برهانه }
$$

Sampai dengan bait:

15 Ibid., 78

16 Thaha bin Husain al-Thaqaf, Fuyudad al-Bahr al-Mail, 172-180 
Achmad Syukron Abidin

Nilai-Nilai Tasawuf Dalam Kitab Simthu Ad-Durar Karya Habib Ali bin Muhammad Al-Habsyi

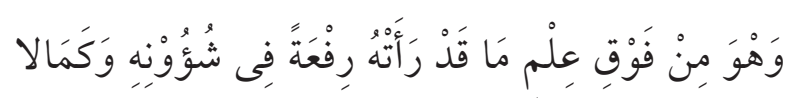

Selain itu beliau menyuruh oráng untuk membacakan khotbahnya di hadapan beliau.

Pada hari selasa pembuka Rabiul Awwal 1327 H, Habib Ali bin Muhammad al-Habsyi menyuruh seseorang untuk membacakan maulid yang menjadi pembukaan pembukaan pada karyanya dengan pembukaan yang agung. Pada hari Kamis 10 Rabiul Awwal telah sempurna saduran Simthu ad-Durar dan kemudian dibacakan pada hari itu juga. ${ }^{17}$

Adapun sebab-sebab atau alasan penamaan kitab Simthu adDuraritu tidak dijelaskan oleh pengarang. Namun dalam petikan karya Taha bin Hasan dikatakan tujuan pembuatan kitab tersebut adalah untuk membangkitkan rasa duka cita yang mendalam bagi para muhibbin atas hubungan dan pertalian yang kuat dengan nabi Muhammad.

Jika dilihat masing-masing kata penamaan kitab tersebut, maka secara sederhana bisa diartikan sebagai "Untaian mutiara kisah kelahiran manusia utama; akhlak, sifat dan riwayat hidup nabi”. Mutiara-mutiara itulah yang digubah oleh Habib Ali bin Muhammad al-Habsyi.

Habib Ali kemudian mengomentari sendiri karyanya dengan mengataakan: "jika seorang menjadikan kitab maulidku ini sebagai salah satu wirid atau menghafalnya maka, maka sir atau rahasia junjungan nabi Muhammad akan nampak pada dirinya. Aku mengarang dan mengimlakkanya, namun setiap kali kitab itu dibacakan kepadaku, dibukakan bagiku pintu untuk berhubungan dengan nabi Muhammad. Ucapanku untuk nabi Muhammad adalah maqbul semua. Hal itu dikarenakan cintaku kepada junjungan nabi Muhammad, bahkan dalam tulisan-tulisanku juga maqbul. Bahkan dalam surat-suratku ketika aku menyifati nabi Muhammad, Allah membukakan padaku susunan bahasa yang tidak ada sebelumnya. Ini

17 Husain bin Anis,Biografi Habib Ali al-Habsyi Muallif Maulid Simtud Durarh. 60 
Achmad Syukron Abidin

Nilai-Nilai Tasawuf Dalam Kitab Simthu Ad-Durar

Karya Habib Ali bin Muhammad Al-Habsyi

adalah ilham yang diberikan Allah kepadaku. Dalam surat-suratku ada sifat agung Nabi Muhammad, andaikan nabhani membacanya, tentu ia akan memenuhi kitab-kitabnya dengan sifat-sifat yang agung. ${ }^{18}$

\section{Deskripsi Simthu ad-Durar}

Kitab Simthu ad-Duraradalah kitab yang menjelaskan tentang sejarah nabi agung Muhammad. kitab ini menerangkan riwayat hidup nabi Muhammad dari lahir, diangkat seorang Rasul dan segala mukjizat-mukjizat yang didapatkan beliau. Kitab itu ditulis setelah kitab-kitab maulid yang telah masyhur terlebih dahulu seperti alBarzanji, adz-Dziba'i, Burdah dan lain-lain.

Walaupun esensi kitab Simthu ad-Durar tidak berbeda dengan kitab-kitab maulid yang telah ada, tetapi Simthu ad-Durar mempunyai gaya penulisan sendiri. Simthu ad-Durar sebagai karya sastra pun patut untuk dinikmati. Habib Ali bin Muhammad al-Habsyi menulisnya dengan cita rasa syair yang tinggi.

Kitab itu terdiri dari beberapa pasal yang dipisahkan dengan sigot salawat (Allahumma salli wa sallim asrafa solati wa taslim ala sayyidina wa nabiyyina muhammadinirr'aufurrahim). Adapun susunan isi dalam Simthu ad-Durar adalah sebagai berikut:

1. Salawat pertama: mencakup bentuk-bentuk salawat nabi

2. Salawat kedua: juga mencakup bentuk-bentuk salawat nabi.

3. Pasal yang pertama yang berbunyi (الحمدله القوي سلطانه * الواضح برهانه) adalah merupakan mukadimah dari kitab tersebut yang berisi tentang syukur dan pujian kepada Allah yang memberikan nikmat paling agung yang diberikan kepada manusia seisinya atas terciptanya nabi Muhammad.

4. Pasal ke dua yang berbunyi (تجلى الحق في عالم قدسه الواسع) juga masih berkaitan tentang pujian dan tasbih kepada Allah atas penciptaan nabi Muhammad.

18 Husain Anis, Biografi Habib Ali al-Habsyi Muallif Maulid Simtud Durar, h. 61-62 
5. Pasal ketiga berbunyi(اشهد ان لا اله الا الله وحده لا شريك له شهادة تعرب) mencakup tentang kedua syahadat dan tawasul dengan salawat.

6. Pasal keempat yang berbunyi (اما بعد فلما تعلقت ارادة الله في العلم القديم) di sini Habib Ali menerangkan kekhususan dan keistimewaan nur Muhammad. dikatakan di dalamnya bahwa dikarenakan nur Muhammad wujudlah segala yang ada. Diceritakan pula bahwa nur Muhammad berpindah-pindah dari tulang rusuk satu ke tulang rusuk yang lain, sampai kepada rahim Aminah kemudian lahirlah nabi Muhammad.

7. Pasallima yang berbunyi (وقد آن للقلم ان يخط ما حركته فيه الأنامل)mencakup tentang keutamaan dan keistimewaan nur Muhammad yang berpindah-pindah. Pada pasal tersebut disebutkan hadis-hadis yang menceritakan awal penciptaan nur Muhammad sampai pada mahluk terpilih sebagai nabi paling akhir yaitu nabi Muhammad yang sebelumnya dititipkan kepada sulbi ibunya yaitu Aminah.

8. Pasal keenam berbunyi (ومنُ علقت به هذه الدرة المكنونة) mencakup kemuliaan nur Muhammad sebelum dilahirkan oleh ibu tercinta yaitu Aminah.

9. Pasal ketujuh berbunyi(فحين قرب اوان وضع هذا الحبي) yang menerangkan tentang kisah yang menakjubkan sebelum detikdetik kelahiran Nabi Muhammad.

10. Pasal kedelapan adalah mahalul qiyam yang berisi tentang pujian kepada Nabi Muhammad.

11. Pasal kesembilan berbunyi (طين برز صلى الله عليه وسلم من بطن امه برز رافعاً) adalah pasal yang berisi tentang keajaiban-keajaiban berbarengan dengan lahirnya Nabi Muhammad.

12. Pasal kesepuluh yang berbunyi (ثم انه بعد ان حكمت القدرة بظهورة) mencakup masa-masa kepengasuhan nabi Muhammad yang 
Achmad Syukron Abidin

Nilai-Nilai Tasawuf Dalam Kitab Simthu Ad-Durar

Karya Habib Ali bin Muhammad Al-Habsyi

juga terdapat keajaiban-keajaiban pada masa kepengasuhan di bawah Halimah.

13. Pasal kesebelas yang berbunyi (فنشاءعلى اكمل الأوصاف) adalah masa pertumbuhan nabi Muhammad hingga iya di datangi malaikat yang datang padanya.

14. Pasal ke dua belas yang berbunyi (ثم انه بعد ما نزل عليه الوحي البليغ) adalah pasal yang berisi tentang ajakan dakwah nabi dan mukjizatmukjizat yang dimiliki nabi.

15. Pasal yang ke tiga belas berbunyi (ومن الشرف الذي اختص الله به اشرف) adalah pasal yang secara khusus menceritakan isra' mi'raj nabi Muhammad berikut tentang keajaiban dan kemuliaan yang mencapai maqam tertinggi di antara makhluk Allah.

16. Pasal empat belas berbunyi (وحيث تشرفت الأسماعُ باخبار هذا الحبيب المحبوب) yang menerangkan akhlak kemuliaan Nabi Muhammad.

17. Pasal kelima belas berbunyi (ولقد اتصف من محاسن الأخلاق) yang mencakup juga kemuliaan akhlak nabi Muhammad.

18. Pasal keenam belas adalah pasal berisi doa dan tawasul.

\section{E. Analisis Isi Nilai-Nilai Tasawuf dalam Simthu ad-Durar Karya Habib Ali bin Muhammad al-Habsyi}

\section{Syukur}

Banyak ulama mendefinisikan arti syukur, di antaranya menurut Ibnu Qayyim sebagaimana dikutip oleh Abdul Qadir Isa ia mengatakan syukur adalah kesinambungan hati untuk mencintai sang Pemberi nikmat, kesinambungan anggota badan untuk menaatinya dan kesinambungan lisan untuk mengingat dan memujinya. ${ }^{19}$

Bersyukur adalah menisbatkan anugerah kepada pemiliknya yang sejati dengan sikap kepasrahan, makna syukur bukan hanya secara lisan tapi juga dengan anggota lain yaitu hatinya juga bersyukur

19 Syaikh Abdul Qadir Isa, Haqa>iq at-Tashawwuf, Terj. Dari Hakekat Tasawuf oleh. Khairul Amru Harahap dan Afrizal Lubis, (Jakarta: Qishti Press, 2011), h. 267 
Achmad Syukron Abidin

Nilai-Nilai Tasawuf Dalam Kitab Simthu Ad-Durar Karya Habib Ali bin Muhammad Al-Habsyi

dan tindakan-tindakannya tidak lepas dari apa yang diperintahkan dan menjauhi apa yang dilarang. ${ }^{20}$ Syukur Habib Ali dalam Simthu ad-Durar bisa dilihat, seperti kalimat:

$$
\text { الحمدللهالقوي سلطانه }
$$

Segala puji bagi Allah, yang amat teguh kekuasaan-Nya. ${ }^{21}$

Selain itu, Habib Ali juga mengucapkan rasa syukur atas diutusnya Nabi Muhammad.

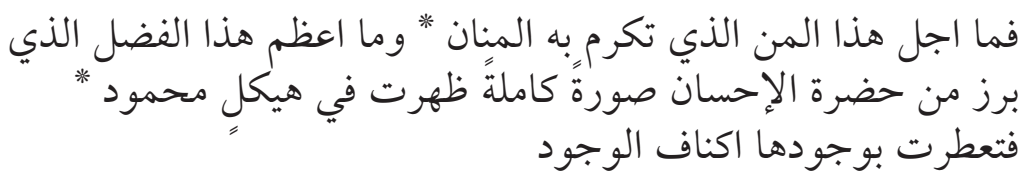

"Aduhai, betapa agung anugerah ini. Dilimpahkan oleh Dia Yang

Maha Pemurah, Maha Pemberi. Betapa tinggi nilai keutamaan

ini. Datang dari Tuhan Sumber segala ihsan. Karunia teramat

sempurna. Dalam bentuk insan terpuji.". 22

Menurut Habib Ali al-Habsyi syukur dengan lisan adalah nikmat yang besar. Manusia menerima beban lebih besar pada saat mereka menerima nikmat dibandingkan dengan memperoleh bencana. Karena bencana menuntut kesabaran, dan manusia mampu bersabar sedangkan kenikmatan perlu disyukuri padahal hanya sedikit orangorang yang bersyukur. ${ }^{23}$ Pendapat Habib Ali ini sesuai dengan firman Allah surat Saba ayat 13:

Dan sedikit sekali dari hamba-hamba yang bersyukur.

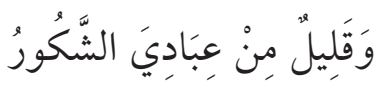

Dalam hal antara kekayaan dengan kemiskinan lebih utama mana? Menurut Habib Ali al-Habsyi sama-sama utamanya antara orang kaya yang bersyukur dan orang miskin yang bersabar. Karena kekayaan tidak disertai dengan rasa syukur, dan pengetahuan antara

20 Muhammad Sanusi, Ummul Barahin, h. 10

21 Ali in Muhammad al-Habsyi, Simtut Durar: fi Akhari Maulidi Khairil Basar, (Solo: Pustaka Zawiyah, tt) h. 16

22 Ibid., h. 21 109

23 Husain Anis, Biografi Habib Ali al-Habsyi Muallif Maulid Simtud Durar, h. 
Achmad Syukron Abidin

Nilai-Nilai Tasawuf Dalam Kitab Simthu Ad-Durar

Karya Habib Ali bin Muhammad Al-Habsyi

hak Allah dengan hak sesama Muslim. Sedangkan kemiskinan bias jadi bencana tanpa dibarengi rasa sabar.

\section{Zuhud}

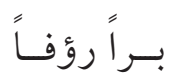

"Sederhana perangainya". ${ }^{24}$

Zuhud secara literal berarti penarikan diri dari kesenangan duniawi dan menolak nafsu rendah. Zuhud adalah sikap melatih diri untuk tidak berhasrat kepada sesuatu yang mubah padahal ada kesanggupan untuk memperolehnya. ${ }^{25}$

Zuhud ini mempunyai sifat-sifat keutamaan dengan sifat yang lain seperti al-qana'ah (merasa cukup dengan apa yang ada), aliffah (menjaga diri dari sifat keburukan), as-sabru (sabar), at-tawadhu' (rendah hati), yang semua itu adalah kemampuan mencegah nafsu untuk mendapatkan kesenangan dunia. Karena Allah SWT tidak menyukai orang-orang yang suka duniawi secara berlebihan maka dengan kita menerapkan sifat-sifat di atas tadi maka kita akan terhindar dari nafsu yang menginginkan kesenangan duniawi. ${ }^{26}$

Zuhud merupakan salah satu maqam yang sangat penting dalam tasawuf. Hal ini dapat dilihat dari pendapat ulama tasawuf yang senantiasa mencantumkan zuhud dalam pembahasan tentang maqamat, meskipun dengan sistematikayang berbeda-beda. Al-Ghazali menempatkan zuhud dalam sistematika: al-Tawbah, al-Sabr, al-Faqr, alZuhd, al-Tawakkul, al-Mahabbah, al-Ma'rifah, dan al-Rida. Sedangkan al-Tusi menempatkan zuhud dalam sistematika: al-Tawbah, al-Wara, al-Zuhd, al-Faqr, al-Sabr, al-Rida, al-Tawakkul, dan al-Ma'rifah. ${ }^{27}$

Habib Ali juga mengambil pendapat para ulama yang menempatkan zuhud sebagai akhlak, sehingga dapat dipetakan bahwa pemikiran Habib Ali al-Habsyi juga mengambil pendapat para ulama

24 Ali in Muhammad al-Habsyi, Simtut Durar: $f$ A Akhari Maulidi Khairil Basar. h. 55 141

25 Zaprulkhan, Ilmu tasawuf, Sebuah Kajian Tematik, (Depok: RajaGrafindo, 2016) h.

26 Ibid., 142

27 Abu Nahsr al-Tusi, al-Luma' (Mesir: Dar al-Kutub al-Hadithah, 1969), 65. 
Achmad Syukron Abidin

Nilai-Nilai Tasawuf Dalam Kitab Simthu Ad-Durar Karya Habib Ali bin Muhammad Al-Habsyi

yang menempatkan zuhud sebagai akhlaq, sehingga dapat dipetakan bahwa pemikiran Habib Ali tentang zuhud berbasis pada prilaku Nabi sebagai dasar pijakannya.

\section{Nur Muhammad}

Nur Muhammad dalam tasawuf mempunyai pembahasan mendalam nur Muhammad disebut juga haqiqatul muhammadiyah. Perbedaan di antara keduanya adalah umpama benda dengan namanya. Hakikat adalah konsep benda dalam alam idea, sedangkan nama ialah sebutan bagi ide suatu hakikat. Dari segi peringkat kewujudannya perbedaan antara keduanya adalah haqiqatul muhammadiyah tercetus pada martabat ketuhanan dan nur Muhammad terwujud pada martabat hamba. Dengan demikian haqiqatul muhammadiyah bersifat qadim sedangkan nur Muhammad bersifat baru. ${ }^{28}$

Terminologi nur Muhammad adalah istilah yang digunakan oleh para sufi yang beraliran tasawuf falsafi. Seperti al-Hallaj, Ibnu Arabi dan al-Jilli. Nur Muhammad tidak persis identik dengan pribadi nabi Muhammad. Nur Muhammad sesungguhnya bukanlah persona manusia yang lebih dikenal sebagai nabi dan rasul terakhir. Dalam Simthu ad-Durardibahas pembahasan mengenai nur Muhammad:

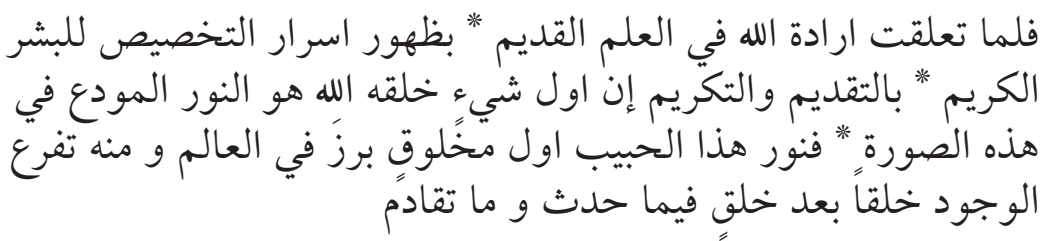

"Bahwa sesuatu yang mula pertama dicipta Allah. Ialah nur yang tersimpan dalam pribadi ini. Maka nur insan tercinta inilah. Makhluk pertama muncul di alam semesta. Darinya bercabang seluruh wujud ini. Ciptaan demi ciptaan. Yang baru datang ataupun yang sebelumnya". ${ }^{29}$

Pendapat ini sejalan dengan pendapat-pendapat para sufi di antaranya adalah Al Hallaj mengatakan bahwa dalam kejadian, Nur

28 Cyril Glasse, Ensiklopedi Islam Ringkas, trj. Gufron A. Mas'adi, (Jakarta: Raja Grafindo Persada, 2002), 309

29 Ali in Muhammad al-Habsyi, Simtut Durar: fi Akhari Maulidi Khairil Basar, h. 26 
Achmad Syukron Abidin

Nilai-Nilai Tasawuf Dalam Kitab Simthu Ad-Durar

Karya Habib Ali bin Muhammad Al-Habsyi

Muhammad-lah yang awal namun dalam kenabian, dialah yang akhir. Al-Haq adalah sama dengan Nur Muhammad, dengan dialah hakikat itu. Dia yang pertama dalam hubungan dan yang akhir dalam kenabian. Dialah yang batin dalam hakikat dan yang lahir dalam makrifat. Nur Muhammad itulah pusat kesatuan alam, dan pusat kesatuan nubuwat segala Nabi, dan Nabi-nabi itu nubuwatnya, atau pun dirinya hanyalah sebagian saja dari pada cahaya Nur Muhammad itu. Segala macam ilmu, hikmat dan nubuwat adalah pancaran belaka dari sinarnya. ${ }^{30}$

Habib Ali al-Habsyi juga menguatkan konsepnya tentang nur Muhammad dengan mengambil dari hadis. Ada dua hadis yang disebutkan dalam Simthu ad-Durar yang menerangkan tentang nur Muhammad. yang pertama hadis yang diriwayatkan dari Abdul Razak dengan sanad dari Jabir bin Abdillah. Yang berbunyi:

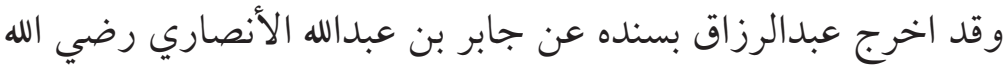

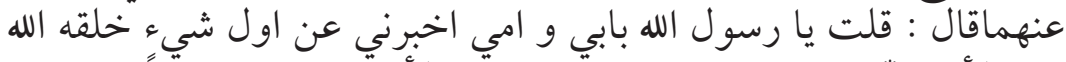

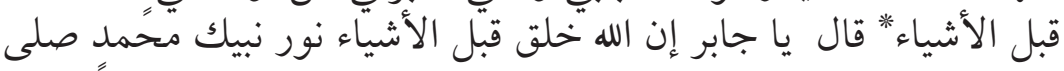

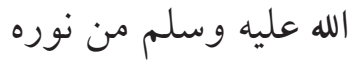

Sebagai mana di riwayatkan Abdurrazzaq. Dengan sanadnya yang sampai pada Jabir bin Abdullah Al-Anshari, semoga Allah meridhai keduanya. Bahwasanya ia pernah bertanya, "Demi ayah dan ibuku, ya Rasulullah, Beri tahukanlah kepadaku tentang sesuatu. Yang diciptakan Allah sebelum segalanya yang lain. Jawab beliau, "Wahai Jabir, sesungguhnya Allah, Telah menciptakan nur nabimu, Muhammad, dari nurnya. Sebelum sesuatu yang lain". ${ }^{31}$

Sedangkan hadis kedua yang diriwayatkan abu Hurairah, yang berbunyi:

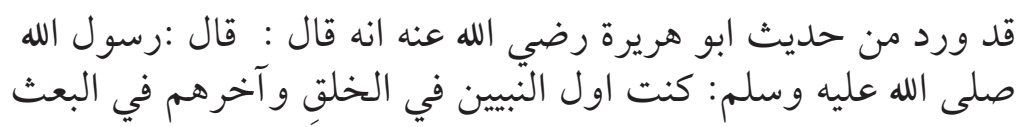

30 Hamka, Tasawuf, Perkembangan dan Pemurniannya, (Jakarta : Pustaka Panjimas, 1984) 123

31 Ali in Muhammad al-Habsyi, Simtut Durar: fi Akhari Maulidi Khairil Basar, h. 27 
Achmad Syukron Abidin

Nilai-Nilai Tasawuf Dalam Kitab Simthu Ad-Durar Karya Habib Ali bin Muhammad Al-Habsyi

Dan telah diriwayatkan oleh Abu Hurairah, Bahwasanya Nabi SAW telah bersabda, 'Aku adalah yang pertama di antara para nabi dalam penciptaan. Namun yang terakhir dalam kerasulan... ".32

Menurut Habib Ali al-Habsyi masih banyak hadis-hadis lain yang menceritakan tentang nur Muhammad.

$$
\text { وقد تعددت الروايات بانه اول الخلق وجودا و اشرفهم مولودا }
$$

Banyak pula riwayat lain menyatakan. Bahwa beliaulah yang pertama adanya. Dan termulia di antara mereka semua. Habib Ali juga menjelaskan proses nur Muhammad sampai pada Nabi Muhammad, Habib Ali juga menjelaskan dalam Simthu ad-Durar:

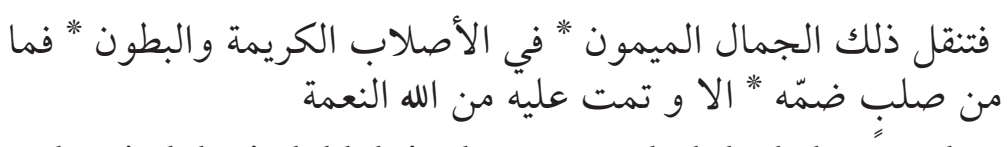

Dan berpindah-pindahlah ia dengan segala keberkahan. Dalam sulbi-sulbidan rahim-rahimyang mulia. Tiada satu pun sulbiyang merangkumnya. Kecuali beroleh nikmat Allah nan sempurna. ${ }^{33}$

Pendapat Habib Ali al-Habsyi ini hampir sama dengan pendapat dari Ibnu Araby dalam kitab Fusus al-Hikam-nya, beliau berpendapat bahwa: Muhammad adalah ciptaan paling sempurna dari ras manusia. Untuk alasan ini segala sesuatu dimulai darinya dan di tutup dengannya. Sungguh, ia telah menjadi seorang nabi saat Adam masih berupa antara air dan tanah kemudian (ketika ia memanifestasi kepada bentuk manusia) dia adalah penutup para nabi”. ${ }^{34}$

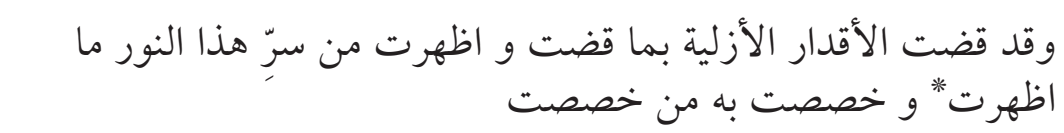

Demikianlah ditetapkan dalam suratan takdir azali. Menampakkan rahasia nur ini. Hanya dalam diri mereka. Yang beroleh kekhususan dan keistimewaan. ${ }^{35}$

32 Ali in Muhammad al-Habsyi, Simtut Durar: fi Akhari Maulidi Khairil Basar, h. 27

33 Ali in Muhammad al-Habsyi, Simtut Durar: fi Akhari Maulidi Khairil Basar, h. 23

34 Muhyiddin Ibnu Arabi, Fusus al-Hikam, (Bairut: Dar al-Kitab al-Arabi, tt), 214

35 Ali in Muhammad al-Habsyi, Simtut Durar: fi Akhari Maulidi Khairil Basar, h. 23 
Achmad Syukron Abidin

Nilai-Nilai Tasawuf Dalam Kitab Simthu Ad-Durar

Karya Habib Ali bin Muhammad Al-Habsyi

Pada penggalan Simthu ad-Duror diatas menegaskan bahwa nur Muhammad sudah dijaga sedemikian rupa oleh Allah. Nur yang sudah dititipkan pada sulbi-sulbi yang suci dan terjaga dari hal-hal yang buruk. Nur yang sudah dijamin kemuliaannya di dunia dan di akhirat, hingga sampai pada nabi Ibrahim dan sampai pada Ismail. Bila dilihat dengan jeli dan meresapi alur sejarahnya, pasti akan timbul efek dari pemaknaan potongan Simthu ad-Duror ini, efek itu berupa perjuangan panjang nur Muhammad yang berpindah-pindah dari sulbi satu ke sulbi yang lain dengan kekhususan yang dimiliki seseorang yang dititipi nur tersebut.

\section{F. Mahabbah dalam Simthu ad-Durar}

Simthu ad-Durar sebagai kitab yang menceritakan kisah Nabi Muhammad adalah suatu bentuk cinta Habib Ali bin Muhammad alHabsyi, ini tergambar dalam wasiat beliau:

"jika seorang menjadikan kitab maulidku ini sebagai salah satu wirid atau menghafalnya, maka sir atau rahasiajunjungan Nabi Muhammad akan tampak pada dirinya. Aku mengarang dan mengimlakkannya, namun setiap kali kitab itu dibacakan kepadaku, dibukakan bagiku pintu untuk berhubungan dengan Nabi Muhammad. Ucapanku untuk Nabi Muhammad adalah maqbul semua. Hal itu dikarenakan cintaku kepada junjungan Nabi Muhammad, bahkan dalam tulisan-tulisanku juga maqbul."

Sebagai rasa cinta Habib Ali al-Habsyi dalam menulis tentang kisah, keutamaan-keutamaan, dan akhlak Nabi Muhammad dalam Simthu ad-Durar-nya:

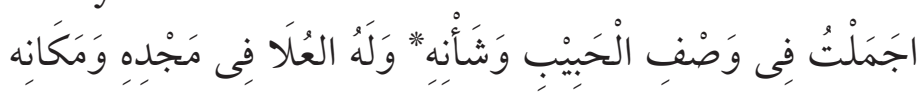

Telah kusimpulkan sifat-sifat insan tercinta ini, dalam dirinya terdapat kemuliaan dengan segala bentuknya. 


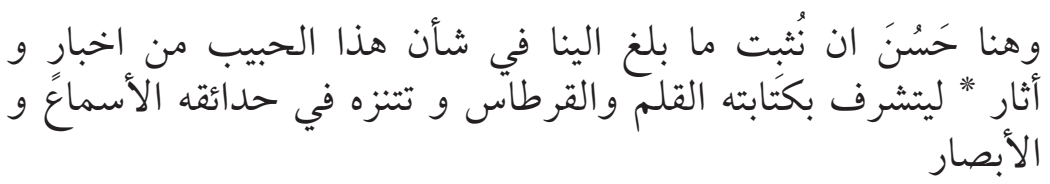

Dan di sinilah sepatutnya kutuliskan. Apa yang telah sampai ke pengetahuanku. Tentang berita dan kisah insan tercinta ini. Agar kalam dan kertas beroleh kemuliaan. Pendengaran dan penglihatan pun berkesempatan, Bertamasya dalam tamantamannya yang indah memesona. ${ }^{36}$

Menurut Habib Ali al-Habsyi salah satu tanda cinta kepada Allah adalah cinta kamu kepada para walinya. Dan salah satu tanda cinta Allah kepadamu adalah cinta para walinya kepadamu. Sebab mereka adalah perantara antara kau dan tuhanmu. Kadangkala cinta bisa tumbuh dari seorang Nabi atau wali. ${ }^{37}$

Cinta kepada nabi Muhammad juga adalah salah satu jalan menuju cinta kepada Allah, karena cinta Allah kepada Nabi Muhammad sangat besar. Habib ali menyontohkan kisah seorang wanita Yahudi:

Suatu ketika di hari yang sangat panas Rasulullah berteduh di bawah rumah seorang wanita Yahudi. Wanita itu sangat membenci Rasulullah sehingga menutup semua jendela dan pintunya agar tidak melihat Rasulullah. Ia menutup telinganya agar tidak mendengar suara Rasulullah. Lalu Jibril datang kepada Rasulullah dan berkata: menyingkirlah dari naungan ini sebab wanita pemilik rumah ini sangat membencimu.

Tak lama kemudian Jibril datang kembali dan memerintahkan nabi untuk kembali rumahnya. Karena Allah sudah memberinya hidayah untuk memeluk Islam berkat berteduhnya Nabi di depan rumahnya.

Setelah Rasulullah kembali berteduh, wanita itu keluar untuk menemuinya, lalu wanita itu berkata kepada Rasulullah. " demi Allah,

36 Ali in Muhammad al-Habsyi, Simtut Durar: $f i$ Akhari Maulidi Khairil Basar, h. 26

37 Husain Anis, Biografi Habib Ali al-Habsyi Muallif Maulid Simtud Durar, h. 130132 
Achmad Syukron Abidin

Nilai-Nilai Tasawuf Dalam Kitab Simthu Ad-Durar

Karya Habib Ali bin Muhammad Al-Habsyi

tadi kau adalah manusia yang paling kubenci. Namun sekarang tiada manusia yang aku cintai selain engkau”. Lalu ia masuk Islam. ${ }^{38}$

Menurut Habib Ali al-Habsyi cerita di atas adalah contoh kecil dari keberkahan Nabi Muhammad dikarenakan kecintaan Allah pada Nabi Muhammad yang sangat besar. Untuk mendapatkan cinta dari Allah seorang hamba haruslah mengikuti apa yang diajarkan Rasulullah. Ini sesuai firman Allah dalam Al-Qur'an surat al-Imran ayat 31 yang berbunyi:

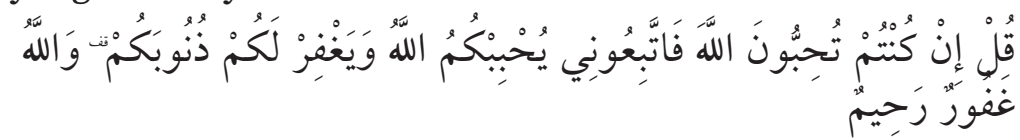

Katakanlah Jika kamu (benar-benar) mencintai Allah, ikutilah aku, ikutilah aku, niscaya Allah mengasihi dan mengampuni dosa-dosamu. Allah Maha Pengampun lagi Maha Penyayang.

Dari ayat di atas bias diambil keterangan bahwa Cinta kepada Rasulullah SAW sederajat dengan cinta kita kepada Allah SWT. Ittiba' atau keikutsertaan selalu bersamaan dengan cinta kepada yang diikuti. Dengan izin Allah, pada saat kita mencintai orang yang kita ikuti, yaitu Muhammad saw., kita pun akan menampakkan kecintaan kepada pencipta alam raya, rabb semesta alam. Derajat (kedudukan) yang agung seperti itu selalu menjadi dambaan setiap muslim.

Perwujudan cinta Habib Ali bin Muhammad al-Habsyi kepada Allah adalah dengan mencintai Rasul-Nya yaitu Muhammad. Selain itu, seorang hamba yang mengharapkan cinta dari Allah harus mengosongkan hatinya dari cinta duniawi. Ini terlihat dari komentar Habib Ali al-Habsyi, kalau mereka mau dengan rezeki yang cukup untuk hidup, namun mereka menghendaki rumah besar, kendaraan bagus, pakaian bayak, makanan lezat, dan lain-lain ujian.

Dengan berbagai keinginan itu mereka mengharapkan cinta Allah Bagaimana mungkin kecintaan kepada Allah menempati hati yang telah penuh dengan kecintaan pada benda-benda lain. ${ }^{39}$

38 Husain Anis al-Habsyi, Biografi Habib Ali al-Habsyi Muallif Maulid Simtud Durar, h. 130

39 Ali bin Muhammad al-Habsyi, Indahnya Syair Simthu ad-Durar, penyunting: Husain 
Selain itu juga, bentuk kecintaan kita kepada Allah adalah bentuk ketaatan kepada Allah. Karena seorang pencinta berani mengorbankan apa saja demi yang dicintai. Bukti pengorbanan seorang hamba kepada Allah adalah dengan ketaatanya dan menjauhi segala larangannya. Selain itu juga seorang hamba mengosongkan hatinya dari selain Allah. Seperti ucapan Habib Ali al-Habsyi: mana tanda-tanda cinta, Mana tubuh yang kurus, Mana bibir yang kering, Mana tangisan, Manakah penyesalan, Manakah usaha, Jika kau mencintai seseorang, kau akan bersungguh-sungguh melayani dan mendekatkan diri padanya. Manakah tanda-tanda cintamu kepada Allah. ${ }^{40}$ Penggambaran cinta kita kepada Allah bukan saja dengan lisan, tetapi harus diikuti dengan perbuatan.

\section{G. Kesimpulan}

Kitab Simthu ad-Durar sebagai kitab yang menceritakan kehidupan nabi juga tidak lepas dari doktrin tasawuf salah satunya adalah tentang Nur Muhammad. penulis mendapatkan nilai-nilai tasawuf dalam Simthu ad-Durar penulis menggunakan metode analisis isi. Di antara yang ditemukan dalam Simthu ad-Durar tentang nilai tasawuf adalah syukur. Menurut Habib Ali al-Habsyi syukur dengan lisan adalah nikmat yang besar. Manusia menerima beban lebih besar pada saat mereka menerima nikmat dibandingkan dengan memperoleh bencana. Karena bencana menuntut kesabaran, dan manusia mampu bersabar sedangkan kenikmatan perlu disyukuri padahal hanya sedikit orang-orang yang bersyukur.

Nilai-nilai zuhud menurut Habib Ali juga mengambil pendapat para ulama yang menempatkan zuhud sebagai akhlak, sehingga dapat dipetakan bahwa pemikiran Habib Ali al-Habsyi juga mengambil pendapat para ulama yang menempatkan zuhud sebagai akhlak, sehingga dapat dipetakan bahwa pemikiran Habib Ali tentang zuhud berbasis pada prilaku Nabi sebagai dasar pijakannya.

Anis, (Solo: Pustaka Zawiyah, tt), h.18

40 Husain Anis, Habib Ali bin Muhammad al-Habsyi, h. 132 
Achmad Syukron Abidin

Nilai-Nilai Tasawuf Dalam Kitab Simthu Ad-Durar

Karya Habib Ali bin Muhammad Al-Habsyi

Selain itu ada nilai-nilai tasawuf falsafi dalam Simthu ad-Durar nilai tasawuf falsafi adalah tentang nur Muhammad. Habib Ali alHabsyi dalam kitab Simthu ad-Durar-nya juga berpendapat sama dengan para ahli tasawuf, bahwa nur Muhammad itu adalah makhluk yang pertama kali diciptakan. Habib Ali al-Habsyi juga menguatkan konsepnya tentang nur Muhammad dengan mengambil dari hadis.

Habib Ali al-Habsyi juga menyebutkan nur Muhammad sudah dijaga sedemikian rupa oleh Allah. Nur yang sudah dititipkan pada sulbi-sulbi yang suci dan terjaga dari hal-hal yang buruk. Nur yang sudah dijamin kemuliaannya di dunia dan di akhirat, hingga sampai pada nabi Ibrahim dan sampai pada Ismail. Bila dilihat dengan jeli dan meresapi alur sejarahnya, pasti akan timbul efek dari pemaknaan potongan Simthu ad-Durar ini, efek itu berupa perjuangan panjang nur Muhammad yang berpindah-pindah dari sulbi satu ke sulbi yang lain dengan kekhususan yang dimiliki person yang dititipi nur tersebut.

Nilai mahabbah dalam Simthu ad-Durar adalah Perwujudan cinta Habib Ali bin Muhammad al-Habsyi kepada Allah adalah dengan mencintai Rasul-Nya yaitu Muhammad. Selain itu juga, bentuk kecintaan kita kepada Allah adalah bentuk ketaatan kepada Allah. Karena seorang pencinta berani mengorbankan apa saja demi yang dicintai. Bukti pengorbanan seorang hamba kepada Allah adalah dengan ketaatannya dan menjauhi segala larangannya.

\section{Daftar Pustaka}

Anis, Husain al-Habsyi, Biografi Habib Ali al-Habsyi Muallif Maulid Simtud Durar, Solo: Pustaka Zawiyah, 20G)

Arabi,Muhyiddin Ibnu, Fusus al-Hikam, Bairut: Dar al-Kitab al-Arabi, tt

Glasse,Cyril, Ensiklopedi Islam Ringkas, trj. Gufron A. Mas'adi, Jakarta: Raja Grafindo Persada, 2002 
Achmad Syukron Abidin

Nilai-Nilai Tasawuf Dalam Kitab Simthu Ad-Durar Karya Habib Ali bin Muhammad Al-Habsyi

Hamka, Tasawuf, Perkembangan dan Pemurniannya, Jakarta: Pustaka Panjimas, 1984

Husain,Thaha bin al-Thaqaf, Fuyudad al-Bahr al-Mail, Madinah: Jami al-Huquq Mahfudah, 2005

Isa,Syaikh Abdul Qadir, Haqa'iq at-Tashawwuf, Terj. Dari Hakekat Tasawuf oleh. Khairul Amru Harahap dan Afrizal Lubis, Jakarta: Qishti Press, 2011

Muhammad, Ali bin al-Habsyi, Indahnya Syair Simtut Duror, penyunting: Husain Anis, Solo: Pustaka Zawiyah, tt Ali bin al-Habsyi, Simtut Durar: fi Akhari Maulidi Khairil Basar, Solo: Pustaka Zawiyah, tt

Nahsr, Abu al-Tusi, al-Luma', Mesir: Dar al-Kutub al-Hadithah, 1969

Zaprulkhan, Ilmu tasawuf, Sebuah Kajian Tematik, Depok: RajaGrafindo, 2016 